\title{
Waardenburg syndrome and myelomeningocele in a family
}

\author{
Sansnee Chatkupt, Surachat Chatkupt, William G Johnson
}

\begin{abstract}
We report the first family with Waardenburg syndrome type 1 and myelomeningocele in which more than one subject was affected with both disorders. The possible association is discussed. Prenatal screening for myelomeningocele is suggested for a family with Waardenburg syndrome type 1 .
\end{abstract}

(f Med Genet 1993;30:83-4)

Waardenburg syndrome type 1 , an autosomal dominant disorder, consists of dystopia canthorum, broad nasal root, narrow nasal tip, pigmentary disturbance (heterochromia iridis, white forelock, and white eyelashes), and sensorineural deafness. ${ }^{1}$ The occurrence of Waardenburg syndrome and spina bifida in the same family has been reported. ${ }^{23}$ However, it is unclear whether the finding is coincidental or the disorders share a common pathogenesis.

We report here a family with Waardenburg syndrome type 1 and myelomeningocele in which the two affected sibs had both disorders.

Division of Genetics, Department of
Obstetrics and Gynecology, Jersey City Medical Center (Seton Hall University), Jersey City, New Jersey, USA.

Surachat Chatkupt

Division of Neurogenetics, Department of Neurology, Robert Wourology, Rob Medical School, New Brunswick, New Jersey, USA. W G Johnson

Correspondence to Dr Sansnee Chatkupt.

Received 13 March 1992. Revised version accepted 8 May 1992 .

\section{Case reports}

The family was ascertained as part of a linkage study for neural tube defects. The proband (III.5, fig 1) was a 4 year old boy who was born with lumbosacral myelomeningocele which was repaired at birth. A ventriculoperitoneal shunt (VP) was inserted because of hydrocephalus. He had typical facial characteristics of Waardenburg syndrome type 1 with lateral displacement of the medial canthi and a broad nasal root (fig $2 \mathrm{~A}$ ). His brother (III.6) was also born with lumbosacral myelomeningocele repaired at birth and hydrocephalus. A VP shunt was inserted shortly after birth. He also had Waardenburg syndrome. He had a white forelock which disappeared after the newborn period, dystopia canthorum, broad nasal root,

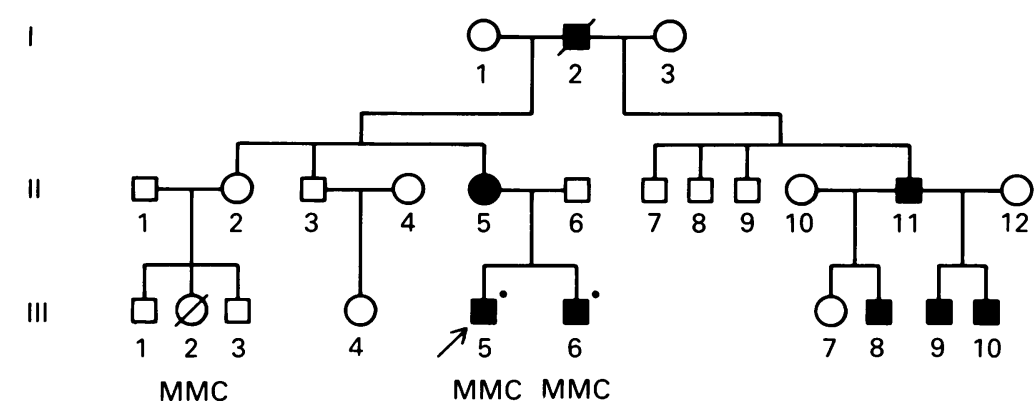

Figure 1 Pedigree of the family. Patients with myelomeningocele are labelled MMC. Dots indicate the family members whose medical records were reviewed. Shaded circles and squares are patients with Waardenburg syndrome. and total deafness (fig 2B). The mother (II-5) had a frontal white blaze of hair, dystopia canthorum, and broad nasal root (fig 2C). Her hearing was normal. The proband's cousin (III-2) was born with myelomeningocele and died at the age of 11 months. There was no evidence of Waardenburg syndrome in this child. Patient II-11 (fig 1) had a white forelock and slight hearing difficulty. One of his children (III-8) had facial characteristics of Waardenburg syndrome as well as deafness. His other two children (III.9 and III.10) had only hearing impairment. The facial features were less characteristic in the proband's grandfather (I.2). He did not have a white forelock or hearing impairment.

\section{Discussion}

Spina bifida has been noted to occur in at least four patients with Waardenburg syndrome. ${ }^{23}$ Myelomeningocele has also been reported in a father of a patient with Waardenburg syndrome. ${ }^{2}$ Recently Carezani-Gavin et $a l^{4}$ reported the first patient who had both myelomeningocele and Waardenburg syndrome and suggested prenatal screening for myelomeningocele when the conceptus is at risk for Waardenburg syndrome. Our family is the first to be reported in which more than one subject was affected with both Waardenburg syndrome and myelomeningocele. This finding suggests that the association of the two disorders may be more than a chance occurrence. Waardenburg syndrome type 1 has been mapped ${ }^{5}$ to the long arm of human chromosome $2(2 q)$. This region is homologous to the region of the mouse genome bearing the splotch ( $\mathrm{Sp}$ ) mutation, ${ }^{5}$ an animal model for neural tube defects. ${ }^{6}$ Mutation in HuP2 has been reported in patients with Waardenburg syndrome type $1 .^{78} \mathrm{HuP} 2$ is the human homologue of the Pax-3 paired box gene which causes the splotch ( $\mathrm{Sp}$ ) phenotype. ${ }^{78}$ It has been suggested that the pathogenesis of both Waardenburg syndrome and myelomeningocele is the result of abnormalities related to neural crest cell emigration. ${ }^{9}$ Genetic susceptibility for myelomeningocele, a known multifactorial disorder, could involve a mutation in HuP2. This could represent pleiotropic effects of the same mutation, perhaps modified by environmental factors in the case of myelomeningocele. The occurrence of myelomeningocele or spina bifida in family members whose relatives had only Waardenburg syndrome $^{23}$ supports this hypothesis. It is also possible that a genetic susceptibility locus for myelomeningocele is located near the gene for Waardenburg syndrome type 1 and the 


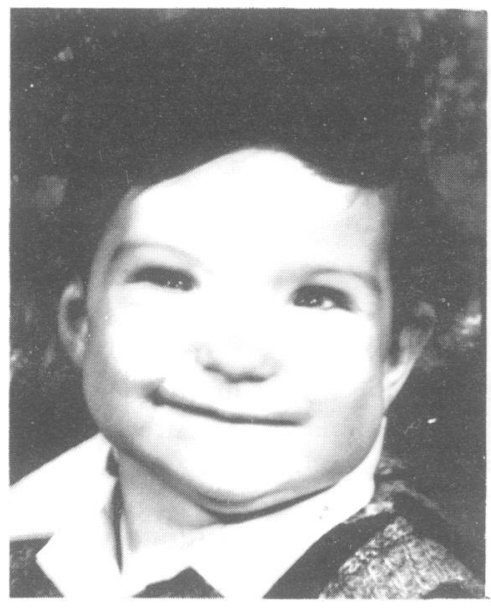

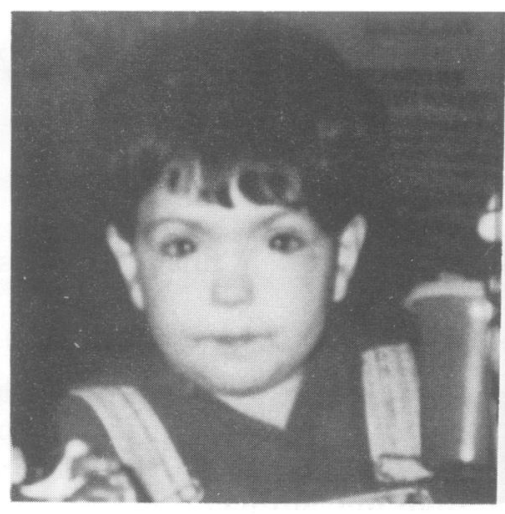

$B$

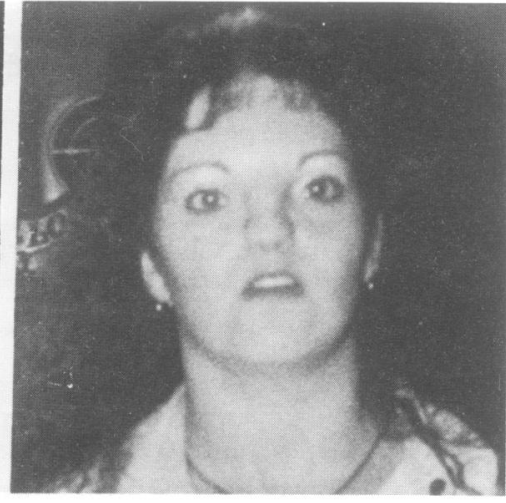

C

Figure 2 The proband $(A)$ had characteristic facial features of Waardenburg syndrome with dystopia canthorum, narrow nasal tip, and broad nasal root. The proband's brother (B) had similar facial features: a white forelock in the newborn period, which disappeared, and deafness. The proband's mother $(C)$ had a white forelock, similar facial features, but no hearing impairment.

association is related to a contiguous gene syndrome rather than to pleiotropy. A deletion in this region could then produce both disorders. This family also supports the idea that prenatal screening for myelomeningocele should be considered in a family with Waardenburg syndrome type 1 .

We are grateful to the family for their cooperation and to the Foundation of UMDNJ and the NIH (grants 2 S07 RR 05393 and 1 R29 NS29893) for their support.

1 McKusick VA. Mendelian inheritance in man. Baltimore: Johns Hopkins University Press, 1988:764.
2 Pantke OA, Cohen MM Jr. The Waardenburg syndrome. Birth Defects 1971;7:147-52

3 Arnvig J. The syndrome of Waardenburg. Acta Genet 1959;9:41-6.

4 Carezani-Gavin M, Clarren SK, Steege T. Waardenburg syndrome associated with myelomeningocele. $A m \mathcal{H}$ Med Genet 1992;42:135-6.

5 Asher JH Jr, Morell R, Friedman TB. Waardenburg syndrome (WS): the analysis of a single family with a WS1 drome (WS): the analysis of a single family with a WS1 chromosome 2q. Am $\mathcal{F}$ Hum Genet 1991;48:43-52.

6 Winter RM. Malformation syndromes: a review of mouse/ human homology. $₹$ Med Genet 1988;25:480-7.

7 Tassabehji M, Read AP, Newton VE, et al. Waardenburg's syndrome patients have mutations in the human homologue of the Pax-3 paired box gene. Nature 1992;355:636. 8 Baldwin CT, Hoth CF, Amos JA, O da-Silva E, Milunsky A. An exonic mutation in the $H u P 2$ paired domain gene causes Waardenburg's syndrome. Nature 1992;355:637-8.

9 Moase CE, Trasler DG. Splotch locus mouse mutants: models for neural tube defects and Waardenburg syndrome type 1 in humans. $f$ Med Genet 1992;29:145-51. 